\title{
Retraction of Based on Environmental Education to Study the Correlation between Environmental Knowledge and Environmental Value
}

\author{
Shubo Liu ${ }^{1^{*}}$, Liqing Guo ${ }^{2}$
}

Issue Date: $\quad 2$ February 2019

Original Article: Based on Environmental Education to Study the Correlation between Environmental Knowledge and Environmental Value

EURASIA J. Math., Sci Tech. Ed (2018), 14(7), 3311-3319.

https:// doi.org/10.29333/ejmste/91246

This document states that the Article is retracted. All authors agree to the retraction of the Article.

\section{http://www.ejmste.com}

